This is a post-peer-review, pre-copyedit version of an article published in Comparative European Politics. The definitive publisher-authenticated version: Freire A. and Belchior A.M. What left and right means to Portuguese citizens. Comparative European Politics (2011) 9, 145-167 is available online at:

http://dx.doi.org/10.1057/cep.2009.14 


\section{What left and right means to Portuguese citizens}

André Freire and Ana Maria Belchior

Paper initially submitted for consideration to Comparative European Politics

June 30, 2008

Revised version submitted on April 9, 2009

Second revision submitted on September 25, 2009

Accepted on October, 19, 2009 


\title{
What left and right means to Portuguese citizens
}

\begin{abstract}
Although previous studies have concluded that, in comparative terms, Portuguese citizens exhibit low levels of social, value and partisan left-right attitude anchoring, the truth is that the items used in these studies are rather limited. Moreover, the meaning attributed by voters to each ideological camp was never studied. This study seeks to overcome these limitations. The paper reiterates that in a comparative perspective, Portugal does exhibit low levels of left-right attitude anchoring. This is the point of departure of the paper and also, it is argued, a good reason to try to further understand this case and extract from it inferences about similar cases. One of this study's major findings is that the meanings attributed to the left-right divide are not clear and structured; moreover, this lack of clarity is positively correlated with low levels of media exposure, education and left-right selfplacement. Although the paper tests hypotheses about how different groups (manual workers vs. other social classes; older vs. younger cohorts; post materialists vs. other value groups) might give different meanings to the left-right divide, the major finding is that media exposure and education are in any case the crucial factors explaining the more or less structured meanings for ideological conflicts.
\end{abstract}

Key-words: left-right ideology, left-right anchoring, Portugal, new politics, old politics 


\section{Introduction}

Ever since the French Revolution the division between left and right has been of fundamental importance in mass politics, particularly in continental Europe (Laponce, 1981). At the individual level, the division between left and right functions as an instrument with which to reduce the complexity of the political universe; while on the systemic level it functions as a code of communication (Fuchs and Klingemann, 1990, 205).

In spite of all the theories about the end of ideology, the end of history, and a certain overcoming of the division between left and right (for a review see Heywood, 2003), the truth is that these same theories have been clothed in an ideological character that, soon after being formulated and defended, were followed either by the appearance of new ideological forms or by the renewed prominence of 'old' ideologies (Heywood, 2003). Moreover, several studies have revealed there is little empirical evidence to support the end of ideology thesis, either at the mass level or at the party system level (Knutsen, 1997; Van der Eijk et al, 2005; Freire, 2006; Dalton, 2006).

Contrary to that which is rather common in other countries (Sani and Montero, 1986; Fuchs and Klingemann, 1990), previous studies of the Portuguese electorate have never been able to systematically study the meaning Portuguese electors themselves attribute to this political divide over left-right orientations (see Freire, 2006, 2008). This is because those studies relied on secondary data analysis and/or the study of left-right orientations was-at best—a subject of secondary importance for the original data collectors. However, a research project entitled 'Participation and Democratic Deliberation', which was recently carried out at the CIES-ISCTE (Centre for Sociological Research and Studies) in Portugal, has overcome these shortcomings. One of the major topics investigated was precisely the meaning and correlates of the left-right divide for 
Portuguese electors; thus, the questionnaire was specifically designed to tap some of the most relevant dimensions of the divide.

In the first section, and after a literature review of the major components that explain left-right placement, the paper begins by concluding that despite using more appropriate indicators to measure each of the three components of the left-right divide, in a comparative perspective Portugal continues to exhibit low levels of left-right attitude anchoring. This is the point of departure of the paper and also, it is argued, a good reason to try to further understand this case and to extract from it inferences about similar cases, i.e., about countries that also have low levels of left-right attitude anchoring.

A set of specific questions designed to measure exactly what the Portuguese mean by the left-right divide were asked in the referred questionnaire; and from the data available concerning this concept, we derive the second objective of the paper: to understand what the Portuguese attribute to each of the two camps in the left-right divide. We want to evaluate whether citizens can distinguish between different ideological positions and accurately (that is, consistently with what is known from political theory and history, etc.) characterise left and right. Additionally, the third objective is to know if that level of consistency is positively correlated with the individual's level of education, media exposure and political interest. Here we also want to know (fourth objective) whether there is a relation between a person's individual location on the scale (e.g., more to the left, the centre or the right) and the substantive meaning that citizen attributes to each ideological camp.

The fifth objective analyzed here concerns the so-called 'old' and 'new' meanings for the left-right divide, demonstrated by scholars studying old and new politics (Inglehart, 1984; Flanagan and Lee, 2003). After a literature review, we test three major hypotheses 
here. The hypotheses underlying those five objectives will be duly presented and based in the respective sections.

\section{Data}

This paper is mainly based upon a survey conducted exclusively in Portugal during spring and summer of 2006 under a CIES-ISCTE research project called 'Participation and Democratic Deliberation', which was directed by José Viegas ${ }^{1}$. The survey was based upon a representative sample of the adult population living in the mainland $(\mathrm{N}=1000)$. The sample is multi-stage probabilistic and the data were collected using face-to-face interviews. Two specific sets of questions included in the survey were especially designed to overcome shortcomings of previous studies, namely: first, to measure more appropriately the anchoring of left-right attitudes; second, to understand and explain what the Portuguese substantively attribute to each camp in the left-right ideological divide. However, in the beginning of the paper and to give a comparative overview of the correlates of left-right self-placement, we also used data from the European Value Study 1999.

\section{The anchoring of left-right attitudes: The Portuguese case in comparative perspective}

Several arguments have been advanced concerning citizens' left-right self-placement (Inglehart and Klingemann, 1976; Huber, 1989; Knutsen, 1997; Freire, 2008). At the mass level, and as a long-term determinant of political behavior, ever since the publication of Inglehart and Klingemann's seminal paper in 1976, there has been a consensus that there are three major components to the left-right self-placement of individuals: social, value and partisan. The social component refers to the connection between the citizen's position in the social structure, their corresponding social identity and their left-right orientation. The 
value component refers to the link between an individual's left-right self-placement and their attitude towards the major value conflicts in Western democratic mass politics. Finally, the partisan component refers to that part of an individual's ideological orientation that reflects mainly partisan loyalties (Inglehart and Klingemann, 1976: 244-5; Huber, 1989; Fuchs and Klingemann, 1990: 207; Knutsen, 1997; Freire, 2008).

Inglehart and Klingemann (1976: 264-9) argue that the impact of the social component on the citizen's left-right orientation is rather small, especially when compared to the partisan dimension. Perhaps because of their poor results, that dimension has been largely neglected (Huber, 1989; Knutsen, 1997), or only considered marginally (Inglehart, 1984-1990). However, in a recent article, Freire (2008) showed that for the social anchors of the citizens' left-right orientations to be properly assessed, they must be correctly specified in three somewhat different dimensions; namely, the socio-structural, the organisational and the identity dimensions. When the model was correctly specified with the addition of the identity dimension, it was possible to reach the conclusion that social factors are an important element in explaining left-right orientations, both in absolute and in relative terms, although more so in some countries than in others.

Nevertheless, Freire's (2008) comparative study was based on secondary data and, as the author himself has recognised, the measures for the (social) identity component were very crude: 'trust in unions', 'trust in large companies' and 'trust in church'. In this paper we follow Freire's approach in respect to the social component. The measures of the three factors that are used to explain each individual's left-right self-placement are presented in Tables A.1 and A.2 in the Appendix. For the structural dimension of the social component, we use social class, education, income and church attendance. For the organisational dimension, we use membership in three types of association: trade unions, employers 
associations, and 'new politics' groupings (e.g., environmentalist, pacifist, human rights, etc.). For the identity dimension we use a series of scales (with a total of 11 points, ranging from 0 - strongly dislikes, to 10 — strongly likes)—one for each movement/organisation— measuring the respondents' attachment to different social groups (trade unions, churches, employers, immigrants' rights, women's rights, or pro-choice movements) (the full text for each and every question can be furnished by the authors upon request).

Given the absence of a direct measure for party identification in several recent comparative surveys of the left-right divide (Huber, 1989; Knutsen, 1997; Freire, 2006a; 2006b; 2006c; 2008), 'voting intention' was used as an equivalent for 'partisan orientations'. However, here we can use direct measures of party identification, including several dummies—one for each party—with 'non-identifiers' as the reference group.

Finally, for the 2006 survey we have several measures of value orientations which are intended to tap the major value conflicts in Western democratic mass politics (socioeconomic, religious, and 'new politics'): see the full text of the questions in Table A.2. These are eight composite additive indices that are based on 17 items first aggregated via a Principal Component Analysis (Varimax Rotation). For each composite index, in Table A.1 we present positive and negative signs referring to the substantive content to which each polarity refers. With all these items we believe that we can produce a more accurate model with which to explain left-right self-placement. For the corresponding indices concerning the European Value Study 1999 data, see Freire, 2008.

The hypothesis to be tested for the first goal of the paper is, therefore, that compared to other European countries, Portugal is expected to show low levels of left-right anchoring (social, value and partisan orientations). Furthermore, since we are using more accurate indicators, social factors and partisan orientations are both expected to demonstrate a higher 
relevance than in previous research concerning Portugal. Overall, we expect an increase in the level of variance explained concerning left-right self-placement.

\section{INSERT}

Table 1: The anchoring of left-right self-placement - the Portuguese case in comparative perspective, 1999 and 2006 - percentage of variance explained (using OLS regressions) by each of the three components of the left-right divide and overall ABOUT HERE

In Table 1 we present the results of the OLS regressions, not only from the 2006 CIES' survey but also from the 1999 (and 1990, only for the Irish case) European Value Study. The dependent variable is individual left-right self-placement, while the independent variables are the three different sets of indicators, each introduced in steps. The introduction of each set of variables in the regression equations in this way allows us to estimate the variance of left-right orientations that can be explained by each one of the three sets of factors (the adjusted $\mathrm{R}^{2}$ ). We can see that in 2006, social factors explain 5.9 per cent of the variance in left-right self-placement among the Portuguese. Thus, in spite of using more appropriate indicators for the social identity component, social factors weigh less than in 1999: 9.0 percent. This finding, which is contrary to our expectations, is not easy to explain but might be related to short-term factors and the differential mobilization of each ideological camp in different political circumstances.

Considering the beta weights (data not shown), we see that religion is the most important factor in explaining left-right self-placement: positive feelings towards the church, as well as membership in religious associations, are closely associated with right- 
wing orientations. The third major factor, attitudes toward movements defending abortion liberalisation, is negatively related to right-wing attitudes. Social class counts almost equally with the previous factor: manual workers place themselves more to the left while members of the 'bourgeoisie and petit-bourgeoisie' place themselves more to the right. No individual value indicator has a significant impact.

Finally, partisan orientations are the single most important factor in explaining the left-right self-placement of citizens, explaining 27.9 per cent of the variance. Moreover, probably due to a more accurate indicator, we can see that this component now weighs more than in previous surveys (18.6 per cent of variance explained in 1999).

All these results are consistent with previous studies with respect to the low degree of left-right anchoring. First, the total variance explained is rather similar to that found in previous studies, although with a small improvement (31.5 and 29.5 per cent, respectively for 2006 and 1999). Second, the major importance of partisan orientations, followed (at some distance) by social factors, was also found in previous studies. Thus, in spite of the refinements to the measures used in this study, in a comparative perspective the results are still consistent with the low level of left-right attitude anchoring of the Portuguese. There was some improvement in the level of variance explained, but not much. Moreover, this was especially due to the use of party identification, instead of the vote; but for the social factors the evidence points in a direction that is opposite to the one expected.

Overall, the present study confirms that Portugal, along with Austria, Belgium, and Ireland, are among the West European countries that exhibit the lowest levels of left-right anchoring: around 30 per cent or less. This aspect of these four countries makes them special cases worthy of closer inspection. ${ }^{2}$ It is precisely because of this divergence from the Western European norm, i.e., from the majority of West European cases analysed in 
Table 1, that the Portuguese case deserves to be re-examined with more emphasis on primary data that are designed to clarify the meaning of the ideological divide and magnitude of left-right attitude anchoring. Namely, since there are low levels of left-right anchoring, we can also expect to have a less structured and a less clear view about the substantive meaning of left and right. Moreover, the Portuguese case can provide some hints about the other Western European cases where a low anchoring of left-right attitudes was also found. In this respect, we should recall that in explaining the countries' differences in the level of left-right attitude anchoring, Freire (2008) found that what best explains these differences is not the age of the democratic regime (separating Portugal, Greece, and Spain from the other polities) but the level of party system polarization (setting apart Portugal, along with Austria, Belgium, and Ireland, from all the other nine countries). If the low clarity of party alternatives is related to low levels of left-right attitude anchoring, it might be also related to a less structured view of each ideological camp - a hypothesis that we cannot test here. Thus, low party system polarization might also be related to citizens' less structured and less clear views on the substantive meaning of left and right.

Before proceeding, a final note should be made. This section is intended to give a comparative overview of the Portuguese case and also to compare the results from the 2006 CIES survey with previous studies, namely Freire (2008) using EVS, but only in terms of the social, value and partisan correlates of left-right self-placement. The rest of the paper, about the meaning of left and right for the Portuguese citizens, has never been done for Portugal (although similar studies with this approach were done for other countries). Understanding what left and right means for the (Portuguese) citizens is a different approach vis-à-vis the one that relies mainly on the analysis of the correlates of left-right. 


\section{The meaning of left and right}

Although the importance of ideology in modern democracies has been proven, the literature admits the existence of substantial changes in the contents customarily associated with the traditional ideological dimension. In reality, the political positions currently adopted by left and right can be said to be entwined in the different party manifestos. In this polarisation, equality and freedom has a key role in the web of political values in which the left is essentially linked to the traditional position of defending social change designed to achieve political, economic and social equality. The state plays a central role in driving forward that change; while the right is identified with the instrumental role of the market in promoting growth and economic efficiency and the conservation of the existing socio-political pattern of hierarchies (Heywood, 2003; Dalton, 2006; Freire, 2008).

Despite that discussion, one aspect of the left-right dimension that has been extensively validated indicates that both political parties and individuals are typically positioned at specific points within a continuum, which can be representative of their positions towards key political issues. However, a number of difficulties can beset expectations concerning the validity of this aspect. For example, Converse (1964) suggests there is a disarticulation between ideology and support for a party: that is, people vote for parties without having a clear commitment to the basic ideological values that underlie them. It is also admitted that only a minority, i.e., the better educated and those with more information, see politics through a political mirror (Converse, 1964; Zaller, 1992). Despite these difficulties, it has been shown that people manage to do quite a good job of locating themselves within the framework of the different ideological families and positioning themselves on either the left or right. 
Regarding the second goal of the paper, considering what we know about the several possible meanings of the left-right divide, both from the perspective of political theory/political history and from that of empirical political science, a set of 19 questions were asked in order to assess what meanings the Portuguese attribute to the left-right divide. For each of these questions the respondent was asked to say whether he or she considered it to be 'more associated with the right', 'more associated with the left' or 'associated neither with the right nor with the left'. The results, which are presented in Table 2, tap many issues that are usually associated with the left-right divide. Thus, respondents were asked to locate several issues that are traditionally associated with the old socio-economic left-right divide (wealth distribution, wealth concentration, privatisations, defence of public services, higher taxes, lower taxes, proximity to trade unions and proximity to employers) and with the division between the so-called 'new left' and 'new right' (the level of citizens' participation in political decisions, orientations towards authority, same-sex marriage, traditional families, environmental protection, quality of life, immigration, etc.).

It should be noted that these issues have been usually associated with either the left or the right (whether old or new) in several comparative studies of mass attitudes in Western societies-although in some countries more than in others (Sani and Montero, 1986; Converse and Pierce, 1986; Fuchs and Klingemann, 1990; Knutsen, 1997; Herrera, 1999; Freire, 2006a; 2006b; 2008). Studies of the left-right orientations of political parties have also pointed in this direction (Kitschelt, 1994; Budge et al, 2001; Benoit and Laver, 2006).

Considering the low levels of left-right attitude anchoring in Portugal, found in the previous section and very much in line with previous comparative research, and 
considering also that one of the major characteristics in the Portuguese party system (Freire, 2008) is its low level of polarization (i.e., low levels of clarity in the policy alternatives presented by parties to voters), our second hypothesis points to the following. We expect to find low levels of clarity and the lack of a structured thinking about the substantive meanings of left and right among the Portuguese.

\section{INSERT}

Table 2: The meaning of right and left for Portuguese citizens (\%)

\section{ABOUT HERE}

In accordance with our expectations (hypothesis two), Table 2 shows that, except for three items, the majority of Portuguese believe these issues are associated with 'neither right nor left'. The only exceptions are wealth concentration and proximity to business, which are mainly associated with the right (51.1 and 43.1 per cent, respectively), and proximity to trade unions, which is mainly associated with the left (49.5 per cent). In each one of the remaining 16 issues, the majority of Portuguese were not able to associate them with either the right or the left; indeed, there was almost a tie in the case of privatisation. With 40.9 per cent thinking it is 'neither right nor left', and 39.8 per cent believing it is 'more associated with the right'. In a way, these results are consistent with the lower levels of left-right recognition and anchoring (in social factors, values and partisan orientations) among the Portuguese found in previous studies (Knutsen, 1997; Freire, 2006; 2006b; 2008), and can be related to the low levels of polarisation at the party system level (Van der Eijk et al, 2005; Freire, 2006a; 2008). 
Abstracting from the 'neither right nor left' answers, we can see that in all but two issues, the majority of answers are consistent with what we know from political history and political theory, concerning the association of each issue with each camp. For example, while increased citizen participation in political decision-making, same-sex marriage, environmental protection, nationalisation and wealth redistribution tend to be associated with the left; issues such as leaving political decision-making to leaders and experts, respect for authority, respect for family and traditional marriage, hawkish opinions regarding the fight against global terrorism, privatisation and wealth concentration are more associated with the right. The exceptions to this are over higher taxation, which is associated with the right, and lower taxation, which is associated with the left-exceptions that clearly contradict the received wisdom from political history about the content of the left-right divide. This anomaly can be interpreted by the old 'non-attitudes' thesis that was originally formulated by Converse (1964) and restated by Zaller (1992), which says that people do not present very coherent and structured attitudes on more complex political issues.

As we have seen, if we abstract from the 'neither right nor left' answers, electors usually present answers that are consistent with what we know about the left-right divide; However, many electors also give responses that are not consistent. Thus, the question of whether consistent responses are positively correlated with an individual's 'level of education', 'media exposure' and 'political interest' arises. If they are, then we can say that part of the inconsistency is due to either a lack of resources and/or political interest (an important set of factors in this respect revealed by previous research: Converse and Pierce, 1986; Fuchs and Klingemann, 1990; Herrera, 1999). To test this third hypothesis, corresponding to the third goal of the paper, we coded responses that were consistent or inconsistent with political history (values 1 and 0 , respectively), or that were "neither right 
nor left' (value 0.5). We also constructed two additive indices: one relating to 'media exposure' (three items measuring the frequency with which the respondent read, listened to or watched the news in the print and broadcast media) and a second relating to political interest (which measured interest in local, national, European and international politics, with a further three items measuring the frequency of the respondent's political discussion with friends, family and colleagues). Higher values reveal higher levels of education, media exposure and political interest. If our hypothesis is correct, we should find positive correlations between these independent variables and the type of meaning that is attributed to left and right: that is, the more resources then the more the responses will be consistent with those expected though academic visions of left and right.

\section{INSERT}

Table 3: Meanings of right and left for Portuguese citizens by education, media exposure and political interest $\boldsymbol{r}$ (Pearson's correlations)

\section{ABOUT HERE}

The correlation between our additive indices (regarding the 19 items) with the independent variables in Table 3 reveals two things. First, it shows that our hypothesis is correct: the greater the resources the more likely it is that the responses will be consistent with what we know about the left-right divide from political history-all the correlation coefficients are statistically significant. Thus, non-consistent answers can hardly be said to be the result of some kind of post-modern syndrome. Second, media exposure is clearly the major factor associated with more consistent answers (0.270), although both education (0.161) and political interest (0.157) also work in the same direction. However, when we 
attempt to explain variation in the additive indices by using OLS regression with the three above mentioned variables (see Table 5 in the next section), we see the following: media exposure is the single most important factor explaining the level of consistence in left-right meaning; education also counts and political interest does not (that is, its impact is not significant). The tolerance diagnosis reveals no problem of multicolinearity (data not shown). Clearly, therefore, the mass media is the more important channel for enabling citizens to form a clear image of the content of left and right, although school also plays a role in this respect. Political interest has no impact once we control for other variables: its impact is completely mediated by the other factors.

The response to this paper's fourth objective also requires a specific analysis. Understanding what meanings the Portuguese attribute to each of the two camps in the leftright divide also requires a response to the question: "Does someone's ideological selfidentification make a significant difference to their recognition of the ideological location of political issues on the left and the right?" The expectations in this respect are not very solidly theorised, but we can say, due to the fact that leftwing ideologies are often more structured and that rightwing ideologies are less so (Heywood, 2003), that there are some reasons to expect more ideological sophistication from left-wingers than from rightwingers. The multivariate analysis presented in Table 4 reveals that after controlling for all the other relevant indicators, right-wingers (those with self-placement positions 7-10 on the 0-10 scale) do in fact demonstrate significantly less consistent ideological meanings when compared to the reference category of people with centrist positions (positions 4-6 on the 010 scale); but for left wingers (positions 0-3), the relationship found in the cross tabulations is not significant. 
Two further notes about the results presented in Tables 3 and 4 are necessary. Some may argue that while they are significant, the correlations are not very strong, and that the level of variance explained (8.2 per cent) points in the same direction. First, we should bear in mind that correlations with individual level data are usually not very strong-especially when we are trying to explain political attitudes (see Knutsen, 1997; Freire, 2006a). Second, the low correlations also indicate that these independent variables do not exhaust the explanations. By using aggregate data, it has been shown that differences in ideological sophistication are larger between countries than between individuals (Freire, 2006a: Chap. 2). Freire (2006a) revealed that the level of ideological sophistication in each country has a positive correlation with the clarity of party alternatives. Given that party alternatives are not very clearly differentiated in Portugal, particularly between the two major parties, this might explain why so many Portuguese cannot locate the political issues and/or why they tend to provide so many inconsistent responses.

\section{The 'old' and 'new' meanings of the left-right divide}

Traditional meanings of the left-right divide are related to the so-called 'old politics' content of political conflict: mainly related to wealth creation and distribution, thus with the class cleavage (Inglehart, 1984; Knutsen, 1997; Dalton, 2008; Freire, 2008). Accordingly, the 'old left' gives more emphasis to socioeconomic equality and to the role of the state in correcting not only market inefficiencies but, most of all, in producing a more equitable distribution of wealth in society. On the contrary, the right not only gives less emphasis to socioeconomic equality but especially gives more importance to the market as the most appropriate mechanism for wealth production and distribution. The class cleavage was the major structural conflict behind this political debate. 'Old politics' also revolved around the 
religious cleavage but, at least since the end of World War II, religion was more a 'domain of identification' than a 'domain of competition' (Sani and Sartori, 1983).

\section{INSERT}

Table 4: Old and new politics meanings of right and left for Portuguese citizens by social class, education, age and post materialist values: $r$ (Pearson correlations) ABOUT HERE

Considering all that, we defined a set of eight issues (see Table 4) related to these old substantive meanings of left and right (wealth concentration and distribution, the role of public services, taxes, proximity to unions or to employers, etc.). Moreover, we constructed an additive index with the answers to these eight items. Like we did for Table 3, we coded the individual responses that were consistent or inconsistent with political history (values 1 and 0 , respectively), or that were 'neither right nor left' (value 0.5 ).

Here, we want to test the following hypotheses, corresponding to the fourth goal of the paper: first, 'manual workers' are more likely to attribute old meanings to the left-right divide than more affluent social classes (routine non-manual workers, service class, and bourgeoisie); second, older people tend to attribute more old meanings to the left-right divide than younger people.

However, it has been argued that new value cleavages have emerged since the 1960's and that they are gaining more prominence in current political conflicts and, last but not least, that they are changing the substantive content of the left-right divide (Inglehart, 1984; Kitschelt, 1994; Flanagan and Lee, 2003). According to Inglehart, due to the existence of long periods of peace and economic growth after World Word II, as well as to 
the existence of extensive networks of social protection (in Western advanced democracies), since the 1960's political conflict has revolved more around issues related to the quality of life, minority rights, citizens' participation in political decisions, etc., than in previous periods. Moreover, the new issue agenda is supported mainly by young, well_ educated, and post materialist individuals; with the reaction against it coming mainly from materialists defending more authoritarian, nationalist, xenophobic and materialist issue agendas. Other authors, like Flanagan and Lee (2003), argued that the new value cleavage is more between authoritarians and libertarians than between materialists and postmaterialists. In any case, these new lines of political conflict are thought to be changing the substantive content of left and right. The 'new left' has subsequently placed greater emphasis on issues related to the quality of life, environmental protection, increased citizen participation (in political decisions, etc.), and the rights of minorities. At least in the beginning, the 'new right' was understood to be mainly a reaction to the 'new left' and the cultural liberalization associated with it. Thus, it emphasized materialist issues, the need to protect traditional institutions and life-styles, and the importance of authority/strong leaders. Xenophobic orientations are also associated with the 'new right'. Therefore, in addition to the previous two hypotheses, we shall add a third one: people supporting postmaterialist values are more likely to attribute new meanings for the left-right divide than people supporting materialist values. ${ }^{3}$

Based on the findings of this literature, we defined a set of eleven issues (see Table 4) related to these new substantive meanings of left and right. Again, we constructed an additive index with the answers to these eleven items (we used the same coding procedures as for 'old politics'). 
Table 4 reveals that neither 'manual workers' nor older people are more likely to identify left-right positions using traditional meanings. Contrary to expectations, there are almost no statistically significant correlations, and the significant ones have very low coefficients. However, we can see that age usually correlates in the expected direction with the additive index (except in three of eight issues where the coefficients are negative); on the other hand, besides being rarely significant, the correlations with social class are more often in a direction counter to what was expected (five coefficients in a set of eight are negative).

In the same vein, it is true that people with post-materialist values do relate the leftright divide to some 'new politics' issues, but the relations are not only weak but also in several cases, they go in the "wrong" direction (five of eleven issues, two of which are significant). No significant correlation was found for age, and there are seven coefficients of eleven in the "wrong" direction. The correlations with the additive index (11 items) are positive in the case of post materialism and negative in the case of age.

After the analysis of the bivariate correlations between the answers concerning both the 'old politics' and the 'new politics' meanings for left and right, we now pass to the multivariate analysis. To test explanations of the old and new meanings for left and right, we not only consider all the relevant variables for each hypothesis but also some other control variables (education, index of media exposure and index of political interest).

\section{INSERT:}

Table 5: Meanings of right and left for the Portuguese explained by education, media exposure, political interest, ideology, social class, age and post materialist values. OLS regressions 


\section{ABOUT HERE}

In Table 5, we test the explanations for the old meanings of the left-right divide. Here we can see that the two major factors explaining congruent answers are education and media exposure: the more educated and informed a person is the more likely he/she is to give answers about the meaning of left and right that are congruent with old meanings for the left-right divide. However, age also has a significant effect: older people are more likely to give answers similar to the well educated and better informed, confirming our second hypothesis. Thus, once we controlled for the other factors, the positive and significant impact of age did come out. However, the level of variance explained is low (5.4 per cent, less than when we used the additive index with the nineteen items), pinpointing that other factors are also working here, and education and political information are more important than age - please note that colinearity diagnosis revealed no relevant problems of multicolinearity.

We tested also the explanations for the new meanings of the left-right divide. Again, what we can see (data not shown due to the lack of significant results/new evidence) is that the two factors explaining congruent answers are media exposure and education. No other variable, namely post-materialism, is related to the attribution of new meanings to the leftright divide, which is contrary to our expectations. Some final remarks are due in this section. It is true that the analysis of the relationship between both "old politics" and "new politics" with the left-right divide at the mass level is usually done by correlating value orientations and individual left-right self-placement (see for example Knutsen, 1997 and Freire, 2008). However, the approach used in the present paper is also valid. Recall that we want to know what meanings the Portuguese think are more associated with the "left", the 
"right", or neither camp (see Table 2 above). Thus, for example, if young people use "new politics" issues more often to define the meaning of the left, and their elders use "old politics" issues more often, we can clearly say that this is an indication of "the old/new contrasts in the meaning of Left/Right".

Moreover, those people that attribute meanings (old or new) to either the left or the right that are congruent with what we know (from history, political science, political theory, etc.) about the substantive content of each one of the ideological camps can be said to be more politically sophisticated than those that give non-congruent answers. For example, those people that relate "more citizen participation in political decisions", "tolerance of same sex marriage", "wealth redistribution", and "Proximity to trade unions" with the left than with the right, can be said to be more politically or ideologically sophisticated than those that give the opposite answers. And that is why we also explained the attribution of meanings (old and/or new) to each camp via media exposure, education, and political interest (for similar procedures, see Converse, 1964; Converse and Pierce, 1986; Fuchs and Klingemann, 1990). Finally, what we found in the present section is that the attribution of either old or new meanings to the left-right divide in Portugal is more a matter of ideological sophistication than old versus new cleavages.

\section{Concluding remarks}

The major findings of the paper are as follows: first, most of the time the meaning the Portuguese citizenry attributes to the left-right divide is not totally clear. With the exception of three specific issues (wealth concentration-which is associated with the right—and the association of the left with unions and of the right with employers), the largest proportion of respondents cannot relate either ideological camp to the policy or value orientations that 
are usually associated with either the left or the right. In fact, there is a modest degree of consensus among people in their identification of the different indicators of the traditional ideological poles, alongside a broad band of consensus with respect to the lack of ideological differentiation across the majority of the indicators. This matches the lower anchoring levels of the left-right divide in social structure, values and party identification. Moreover, this lack of consistency (with the more academic visions of left and right) among the Portuguese is positively correlated with their lower levels of media exposure, education and political interest. Additionally, we also found that right wingers do have less clear and structured views of the substantive content of left and right.

However, although the correlations are significant, the level of variance explained is low; thus, the lack of clarity (in the mind of citizens) is probably also related with other factors-namely the low levels of polarisation at the party system level and the blurring of ideological boundaries by parties and governments (of both the right and the left). Both factors result in making the task of differentiating left and right more difficult for ordinary citizens.

We also analyzed not only the question of the 'old' (issues related with wealth concentration and distribution as well as related with the role of the state and the market in producing and distributing wealth) and 'new' (issues related with quality of life, alternative life styles, citizens' participation in decision making, and minority rights) meanings for the left-right divide, but also tested some hypotheses about what explains the attribution of old and new meanings to ideological conflict (social class, age and post-materialism). We found that the attribution of old meanings to the left-right divide is mainly positively correlated with education and media exposure, although age also plays a role (the older people are more attached to old meanings, as predicted). About the attribution of new 
meanings to the left-right divide, we found that only media exposure and education, but neither post-materialist values nor age, are positively correlated with congruent answers. Thus, more structured views about left and right are mainly dependent on civic engagement and sophistication, not with old and new cleavages.

Considering all of the political changes that have taken place in Europe since the fall of the Berlin Wall and the expansion of neoliberal globalization, we believe there are some major questions for future studies. First, there is a need for a comparative reexamination of the meaning of the left-right divide among European citizens. Second, we must seek to explain the differences between both individuals and countries. Namely, comparative studies about the meaning of left and right to voters are now rather outdated (Sani and Montero, 1986; Converse and Pierce, 1986; Fuchs and Klingemann, 1990; Herrera, 1999) and this gap needs to be filled with more comparative research. Moreover, following our study, we need to know if in countries where citizens share less anchored left-right attitudes (like Portugal and others) voters also share less structured and less clear visions about the substantive meanings of this ideological divide. Additionally, we need to know if, besides civic engagement and left-right self-placement, the (lack of) clarity of policy alternatives presented by parties to voters play a role here (as seems to be the case for the Portuguese). 
INSERT APPENDICES HERE 


\section{References}

Benoit, K. and Laver, M. (2006) Party Policy in Modern Democracies. London: Routledge.

Budge, I, Klingemann, H.-D., Volkens, A., Bara, J. and Tanenbaum, E. (eds.) (2001) Mapping Policy Preferences. Estimates for Parties, Electors and Governments 19451998. Oxford: Oxford University Press.

Converse, P. (1964) The nature of belief systems in mass publics. In: D. Apter (ed.) Ideology and Discontent. New York: Free Press, pp. 206-61.

Converse, P. and Pierce, R. (1986) La gauche et la droite. In P. Converse and R. Pierce (eds.) Political Representation in France. Cambridge: Harvard University Press, pp. 111-150.

Dalton, R. (2006) Social modernization and the end of ideology debate: patterns of ideological polarization. Japanese Journal of Political Science 7(1): 1-22.

Van der Eijk, C., Schmitt, H. and Binder, T. (2005) Left-right orientations and party choice. In J. Thomassen (ed.) The European Voter: A Comparative Study of Modern Democracies. Oxford: Oxford University Press, pp. 167-91.

Flanagan, S., and Lee, A.-R. (2003) The new Politics, culture wars, and the authoritarianlibertarian value change in advanced industrial democracies. Comparative Political Studies, 36(3): 235-271.

Freire, A. (2006) Left-right ideological identities in new democracies: Greece, Portugal and Spain in the Western European context. Pôle Sud: Revue de Science Politique de l’Europe Méridionale II (25): 153-73.

Freire, A. (2008) Party polarization and citizens' left-right orientations. Party Politics 14(2): 189-209. 
Fuchs, D. and Klingemann, H.-D. (1990) The left-right schema. In M. K. Jennings and J. Van Deth (eds.) Continuities in Political Action: A Longitudinal Study of Political Orientations in Three Western Democracies. Berlin: deGruyter, pp. 203-34.

Herrera, R. (1999) The language of politics: a study of elite and mass understandings of ideological terminology in the United States and the Netherlands. In W. Miller et al (orgs.) Policy Representation in Western Democracies, Oxford and New York: Oxford University Press, pp. 59-86.

Heywood, A. (2003) Political Ideologies: An Introduction. Basingstoke: Palgrave Macmillan.

Huber, J. (1989) Values and partisanship in left-right orientations: measuring ideology. European Journal of Political Research 17: 599-621.

Inglehart, R. (1984) The changing structure of political cleavages in western society. In R. Dalton, S. Flanagan and P. Beck (eds.) Electoral Change in Advanced Industrial Democracies: Realignment or Dealignment?. New Jersey: Princeton University Press, pp. 25-69.

Inglehart, R. and Klingemann, H.-D. (1976) Party identification, ideological preference and the left-right dimension among Western mass publics. In I. Budge, I. Crewe and D. J. Fairlie (eds.) Party Identification and Beyond. London: John Wiley, pp. 243-76.

Kitschelt, H. (1994) The Transformation of European Social Democracy. Cambridge: Cambridge University Press.

Knutsen, O. (1997) The partisan and the value-based components of left-right self-placement: A comparative study. International Political Science Review 18: 191-225.

Laponce, J A (1981) Left and Right: The Topography of Political Perceptions. Toronto: University of Toronto Press. 
Sani, G. and Montero, J. R. (1986) El espectro político: izquierda, derecha y centro. In J. Linz and J. R. Montero (eds.) Crisis y Cambio: Electores y Partidos en la España de los Años Ochenta. Madrid: Centro de Estudios Constitucionales, pp. 155-200.

Sani, G. and Sartori, G. (1983) Polarization, fragmentation and competition in Western democracies. In H. Daalder and P. Mair (eds) Western European Party Systems: Continuity and Change. London: Sage, pp. 307-40.

Zaller, J. (1992) The Nature and Origins of Mass Opinion. Cambridge: Cambridge University Press. 
Table 1: The anchoring of left-right self-placement - the Portuguese case in comparative perspective, 1999 and 2006 - percentage of variance explained (using OLS regressions) by each of the three components of the left-right divide and overall

\begin{tabular}{lcccc}
\hline Countries / dates & $\begin{array}{c}\text { Social } \\
\text { Factors }\end{array}$ & Values & $\begin{array}{c}\text { Partisan } \\
\text { orientations }\end{array}$ & Total \\
\hline Portugal 2006 & 5,9 & $-2,3$ & 27,9 & 31,5 \\
Portugal 1999 & 9,0 & 1,9 & 18,6 & 29,5 \\
Spain 1999 & 34,7 & 6,1 & 19,3 & 60,1 \\
France 1999 & 17,6 & 6,9 & 23,5 & 48,0 \\
Great Britain 1999 & 13,3 & 16,7 & 9,5 & 39,5 \\
Greece 1999 & 16,9 & 5,0 & 22,5 & 44,4 \\
Germany 1999 & 13,4 & 10,0 & 20,4 & 43,8 \\
Austria 1999 & 10,1 & 7,0 & 7,2 & 24,3 \\
Italy 1999 & 13,2 & 13,9 & 30,1 & 57,2 \\
The Netherlands 1999 & 9,2 & 17,4 & 19,5 & 46,1 \\
Denmark 1999 & 7,0 & 19,6 & 11,6 & 38,2 \\
Belgium 1999 & 8,6 & 8,4 & 11,5 & 28,5 \\
Sweden 1999 & 14,5 & 25,8 & 23,8 & 64,1 \\
Ireland 1990 & 9,0 & 8,7 & 5,3 & 23,0 \\
\hline
\end{tabular}

Source: CIES-ISCTE, Participation and Deliberation Survey (2006), N = 1000, for Portugal 2006; for all other countries, the European Value Study 1999 data (1990, only for the Irish case) (representative samples of adult populations for each country) was used by Freire, 2006, and Freire, 2008 (Greece), from which we collected the comparative data. 
Table 2: The meaning of right and left for Portuguese citizens (\%)

\begin{tabular}{|c|c|c|c|}
\hline & $\begin{array}{l}\text { More to the } \\
\text { right }\end{array}$ & $\begin{array}{l}\text { More to the } \\
\text { left }\end{array}$ & $\begin{array}{c}\text { Neither right } \\
\text { nor left }\end{array}$ \\
\hline More citizen participation in political decisions & 13.9 & 31.0 & 55.1 \\
\hline Political decisions taken by leaders and experts & 26.8 & 16.8 & 56.4 \\
\hline Respect for freedom of speech & 16.9 & 34.2 & 48.8 \\
\hline Attachment to tradition & 32.9 & 22.7 & 44.3 \\
\hline Respect for authority & 29.2 & 16.6 & 54.2 \\
\hline Respect for family and traditional marriage & 31.1 & 20.3 & 48.5 \\
\hline Wealth redistribution & 17.3 & 35.3 & 47.4 \\
\hline Wealth concentration & 51.1 & 12.5 & 36.4 \\
\hline Privatisation & 39.8 & 19.2 & 40.9 \\
\hline Defence of public services & 17.2 & 32.7 & 50.1 \\
\hline Higher taxes & 36.4 & 15.3 & 48.2 \\
\hline Lower taxes & 14.4 & 34.9 & 50.7 \\
\hline Tolerance of same sex marriage & 9.5 & 40.4 & 50.1 \\
\hline Tolerance of immigration & 12.0 & 33.0 & 55.0 \\
\hline Hard-line on war on terrorism & 21.8 & 17.1 & 61.1 \\
\hline Respect for women's rights & 13.0 & 38.5 & 48.4 \\
\hline Proximity to trade unions & 13.5 & 49.5 & 36.9 \\
\hline Proximity to employers & 43.1 & 15.5 & 41.3 \\
\hline Environmental protection & 11.9 & 28.4 & 59.7 \\
\hline
\end{tabular}

Source: CIES-ISCTE, Participation and Deliberation Survey (2006).

Notes: Average don't know/No answer $=2 ; \mathrm{N}=1000$. The higher percentage for each indicator is presented in italics, and the higher percentage for each indicator concerning 'more to the right' and 'more to the left' is presented in bold. 
Table 3: Meanings of right and left for Portuguese citizens by education, media exposure and political interest: $r$ (Pearson's correlations)

\begin{tabular}{lcccc}
\hline & $\begin{array}{c}\text { Congruent } \\
\text { Answer }\end{array}$ & Education & $\begin{array}{c}\text { Media } \\
\text { exposure }\end{array}$ & $\begin{array}{c}\text { Political } \\
\text { Interest }\end{array}$ \\
\hline More citizen participation in political decisions & left & 0.024 & $0.081^{*}$ & $0.114^{* *}$ \\
Respect for freedom of speech & left & -0.005 & $0.109^{* *}$ & $0.091^{* *}$ \\
Wealth redistribution & left & 0.014 & $0.076^{*}$ & $0.110^{* *}$ \\
Defence of public services & left & 0.048 & $0.085^{* *}$ & 0.026 \\
Higher taxes & left & 0.032 & -0.036 & 0.060 \\
Tolerance of same sex marriage & left & $0.095^{* *}$ & $0.155^{* *}$ & $0.135^{* *}$ \\
Tolerance of immigration & left & 0.065 & $0.107^{* *}$ & 0.056 \\
Proximity to trade unions & left & 0.042 & $0.078^{*}$ & $0.069^{*}$ \\
Environment protection & left & $0.068^{*}$ & $0.095^{* *}$ & $0.097^{* *}$ \\
Political decisions taken by leaders and experts & right & $0.070^{*}$ & $0.134^{* *}$ & -0.011 \\
Attachment to tradition & right & 0.057 & $0.098^{* *}$ & 0.020 \\
Respect for authority & right & 0.046 & $0.080^{*}$ & 0.043 \\
Respect for family and traditional marriage & right & $0.090^{* *}$ & $0.106^{* *}$ & 0.023 \\
Wealth concentration & right & $0.073^{*}$ & $0.166^{* *}$ & 0.036 \\
Privatisation & right & $0.086^{* *}$ & $0.140^{* *}$ & 0.037 \\
Lower taxes & right & 0.022 & -0.007 & 0.032 \\
Hard-line on war on terrorism & right & 0.051 & $0.080^{*}$ & 0.008 \\
Respect for women's rights & right & 0.044 & $0.101^{* *}$ & $0.084^{* *}$ \\
Proximity to employers & right & $0.100^{* *}$ & $0.152^{* *}$ & 0.003 \\
Additive Index (all indicators) & - & $0.161^{* *}$ & $0.270^{* *}$ & $0.157^{* *}$ \\
\hline Source: CIES-ISCTE, Partcipation and & & &
\end{tabular}

Source: CIES-ISCTE, Participation and Deliberation Survey (2006).

$\mathrm{N}=1000 ; * * \mathrm{p}>0.01 ; * \mathrm{p}>0.05$. 
Table 4: Old and new politics meanings of right and left for Portuguese citizens by social class, education, age and post materialist values: $r$ (Pearson correlations)

\begin{tabular}{llcc}
\hline & $\begin{array}{c}\text { Social } \\
\text { Class }\end{array}$ & Age & $\begin{array}{c}\text { Post } \\
\text { Materialist } \\
\text { values }\end{array}$ \\
\hline More citizen participation in political decisions & 0,028 & 0.018 & 0.040 \\
Respect for freedom of speech & 0,023 & 0.019 & 0.038 \\
Tolerance of same sex marriage & 0,006 & -0.001 & 0.024 \\
Tolerance of immigration & 0,023 & -0.014 & -0.005 \\
Environmental protection & $-0,014$ & -0.017 & $0.067^{*}$ \\
Political decisions taken by leaders and experts & $-0,054$ & -0.004 & 0.046 \\
Attachment to tradition & $-0,039$ & -0.036 & $-0.063^{*}$ \\
Respect for authority & $-0,030$ & 0.010 & $-0.061^{*}$ \\
Respect for family and traditional marriage & $-0,036$ & -0.037 & -0.033 \\
Hard-line on war on terrorism & 0,005 & -0.033 & -0.014 \\
Respect for women's rights & $-0,006$ & 0.006 & 0.050 \\
Additive Index of new politics indicators (11 items) & -0.021 & -0.021 & 0.018 \\
\hline Wealth redistribution & 0,054 & 0.024 & 0.044 \\
Defence of public services & 0,017 & 0.040 & 0.040 \\
Higher taxes & $-0,028$ & -0.059 & 0.055 \\
Proximity to trade unions & 0,028 & 0.040 & -0.005 \\
Wealth concentration & $-0,004$ & 0.035 & 0.008 \\
Privatisation & $-0,076^{*}$ & -0.004 & 0.010 \\
Lower taxes & $-0,047$ & -0.040 & -0.031 \\
Proximity to employers & $-0,032$ & 0.014 & -0.005 \\
Additive Index of old politics indicators (8 items) & -0.030 & 0.013 & 0.039 \\
\hline
\end{tabular}

Source: CIES-ISCTE, Participation and Deliberation Survey (2006).

Notes:

1) $\mathrm{N}=1000 ; * * \mathrm{p}>0.01 ; * \mathrm{p}>0.05$.

2) Social class: 1 , Manual workers; 0 , others (non manual workers)

3) Age: interval variable with older people with higher values.

4) Post materialist values: 1 ; Mixed values: 0,5 ; Materialist values: 0 . 
Table 5: Meanings of right and left for the Portuguese explained by education, media exposure, political interest, ideology, social class, age and post materialist values. OLS regressions

\begin{tabular}{lccc}
\hline Dependent variables: & $\begin{array}{c}\text { Meanings of right and left } \\
(2)-\text { Method stepwise }\end{array}$ & $\begin{array}{c}\text { (only) Old meanings of } \\
\text { right and left }(3)-\text { Method } \\
\text { enter }\end{array}$ \\
\hline Age & Beta coefficient & Beta coefficient & Beta coefficient \\
Social class & & $0.108^{* * *}$ \\
Post materialist values & & n.s. \\
Education & $0.093^{* * *}$ & $0.096^{* *}$ & n.s. \\
Media Exposure (index) & $0.242^{* * *}$ & $0.241^{* * *}$ & $0.176^{* * *}$ \\
Political interest (index) & - & - & $0.139^{* * *}$ \\
Left wingers & & - & n.s. \\
Right wingers & & $-0.087^{* *}$ & \\
\hline Adjusted $\mathrm{R}^{2}$ & $7.8 \%$ & $8.2 \%$ & $5.4 \%$ \\
Valid N & 950 & 724 & 802 \\
\hline
\end{tabular}

Source: CIES-ISCTE, Participation and Deliberation Survey (2006).

Notes:

1) $\mathrm{N}=1000 ; * * * \mathrm{p}>0.01 ; * * \mathrm{p}>0.05$

2) Dependent variable: Additive index (19 indicators) about meanings of right and left (see Table 3).

3) Dependent variable: Additive index (8 indicators) about the old meaning of left and right (see Table 4).

4) Left wingers (left-right self-placement/P9 =0-3); reference group (centrists = left-right selfplacement/P9 = 4-6).

5) Right wingers (left-right self-placement/P9 = 7-10); reference group (centrists = left-right selfplacement/P9 = 4-6). 


\section{APPENDIX}

Table A.1: Independent variables to explain left-right self-placement

\begin{tabular}{|c|c|c|}
\hline Social factors & Value orientations & Party identification \\
\hline $\begin{array}{l}\text { Social class D1: } \\
\text { Bourgeoisie and petit-bourgeoisie } \\
v . \text { manual workers }\end{array}$ & $\begin{array}{l}\text { Tolerant }(-) v . \text { xenophobic }(+) \\
\text { attitudes towards immigrants } \\
\text { Moral and religious conservatism } \\
(+) v \text {. secularism }(-)\end{array}$ & $\begin{array}{l}\text { D1: } \\
\text { 1=Left Bloc }(\mathrm{BE}) \\
0=\text { non identifiers }\end{array}$ \\
\hline $\begin{array}{l}\text { Social class D2: } \\
\text { Service class } v \text {. manual workers }\end{array}$ & $\begin{array}{l}\text { Private }(+) \text { or public }(-) \text { social } \\
\text { services }\end{array}$ & $\begin{array}{l}\text { D2: } \\
\text { 1=Popular Party (CDS-PP) } \\
0=\text { non identifiers }\end{array}$ \\
\hline $\begin{array}{l}\text { Social class D3: } \\
\text { Routine non-manual workers } v \text {. } \\
\text { manual workers }\end{array}$ & $\begin{array}{l}\text { Economic liberalism }(+) v \text {. } \\
\text { statism/protectionism }(-) \\
\text { Socio-economic equality }(+) v \text {. } \\
\text { socio-economic inequality }(-)\end{array}$ & $\begin{array}{l}\text { D3: } \\
\text { 1=Communist (PCP-CDU) } \\
0=\text { non identifiers }\end{array}$ \\
\hline Education & $\begin{array}{l}\text { Environmental protection (+) } \\
\text { Libertarian orientation (life-styles) } \\
(+) v \cdot \text { non-libertarian orientation }(-)\end{array}$ & $\begin{array}{l}\text { D4: } \\
1=\text { Socialists }(\mathrm{PS}) \\
0=\text { non identifiers }\end{array}$ \\
\hline Income & $\begin{array}{l}\text { Authoritarian orientation }(+) v \text {. } \\
\text { libertarian orientation }\end{array}$ & $\begin{array}{l}\text { D5: } \\
\text { 1=Liberals (PSD) } \\
0=\text { non identifiers }\end{array}$ \\
\hline Church attendance & & $\begin{array}{l}\text { D6: } \\
\text { 1=Extreme left (MRPP) } \\
0=\text { non identifiers }\end{array}$ \\
\hline
\end{tabular}

Union membership

Member of employer association

Member of religious association

New politics association membership (index)

Feelings towards unions ( $0=$ antipathy; $10=$ sympathy)

Feelings towards large companies

Feelings towards the church

Feelings towards movements defending immigrants

Feelings towards movements defending women's rights

towards movements defending gay and lesbian rights

towards movements defending the liberalisation of abortion

Source: CIES-ISCTE, Participation and Deliberation Survey (2006). 
Table A.2 - Items measuring value orientations in the 2006 (CIES) survey: "P13 People hold different views on political issues. What do you think of the following?"

\begin{tabular}{|c|c|c|c|c|c|}
\hline Please tick one box in each row & $\begin{array}{l}\text { Strongly } \\
\text { agree } \\
\text { (5) }\end{array}$ & $\begin{array}{l}\text { Agree } \\
\text { (4) }\end{array}$ & $\begin{array}{l}\text { Neither } \\
\text { agree nor } \\
\text { disagree } \\
(3)\end{array}$ & $\begin{array}{c}\text { Disagree } \\
\text { (2) }\end{array}$ & $\begin{array}{l}\text { Strongly } \\
\text { disagree } \\
\text { (1) }\end{array}$ \\
\hline $\begin{array}{l}\text { Immigrants should be required to } \\
\text { adapt to Portuguese customs }\end{array}$ & & & & & \\
\hline $\begin{array}{l}\text { Politicians should abstain from } \\
\text { intervening in the economy }\end{array}$ & & & & & \\
\hline $\begin{array}{l}\text { Stronger measures should be taken } \\
\text { to protect the environment }\end{array}$ & & & & & \\
\hline $\begin{array}{l}\text { The law should recognise same sex } \\
\text { marriages }\end{array}$ & & & & & \\
\hline $\begin{array}{l}\text { Women should be given equal } \\
\text { treatment when applying for jobs } \\
\text { and promotions }\end{array}$ & & & & & \\
\hline $\begin{array}{l}\text { People who break the law should be } \\
\text { given stiffer sentences }\end{array}$ & & & & & \\
\hline $\begin{array}{l}\text { Providing a stable network of social } \\
\text { security should be the } \\
\text { government's prime goal }\end{array}$ & & & & & \\
\hline $\begin{array}{l}\text { Income and wealth should be } \\
\text { redistributed towards ordinary } \\
\text { people }\end{array}$ & & & & & \\
\hline $\begin{array}{l}\text { Our democracy requires serious } \\
\text { reform }\end{array}$ & & & & & \\
\hline $\begin{array}{l}\text { Immigrants are good for Portugal's } \\
\text { economy }\end{array}$ & & & & & \\
\hline $\begin{array}{l}\text { Portugal should provide military } \\
\text { assistance to the war on terrorism }\end{array}$ & & & & & \\
\hline $\begin{array}{l}\text { Individual rights and the freedom of } \\
\text { citizens should be respected } \\
\text { under all circumstances }\end{array}$ & & & & & \\
\hline $\begin{array}{l}\text { The opening of world markets } \\
\text { should be promoted to the } \\
\text { benefit of all }\end{array}$ & & & & & \\
\hline $\begin{array}{l}\text { Our religious beliefs should be the } \\
\text { basis for our country's laws }\end{array}$ & & & & & \\
\hline $\begin{array}{l}\text { The couple (or the woman) should } \\
\text { never have the right to decide on } \\
\text { abortion }\end{array}$ & & & & & \\
\hline $\begin{array}{l}\text { Education should be provided } \\
\text { mainly by the state }\end{array}$ & & & & & \\
\hline $\begin{array}{l}\text { Health care should be provided } \\
\text { mainly by the state }\end{array}$ & & & & & \\
\hline
\end{tabular}

Source: CIES-ISCTE, Participation and Deliberation Survey (2006). 
${ }^{1}$ For further information, see www.cies.iscte.pt.

${ }^{2}$ Please note that the factors that determine the differences between Portugal (along with Austria, Belgium, and Ireland) and the majority of the West European countries analyzed in Table 1 are above all the lower level of anchoring of individual left-right self-placement on social factors, partisan loyalties, and value orientations, especially the latter element. The differences are of strength not direction of the relationships (see Freire, 2008).

${ }^{3}$ We used the following standard question (like in EVS 1999) to measure materialist and post materialist value orientations "There is a lot of talk these days about what the aims of this country should be for the next ten years. If you had to choose, which of the things would you say is most important? And which would be the next most important? (First Choice and Second Choice) Maintaining order in the nation; Giving people more say in important government decisions; Fighting rising prices; Protecting freedom of speech; Don't know; No answer".

Number of words (everything considered): 8953.

(8908 words if we exclude the first page, the abstract, and this final note).

November 4, 2009 